\title{
Biocontrol Potential of Four Indigenous Entomopathogenic Nematodes From Kenya
}

\author{
C. N. Ngugi ${ }^{1}$, P. M. Wachira ${ }^{2}$, J. N. Mbaka ${ }^{1}$, S. Okoth ${ }^{2}$, S. Haukeland ${ }^{3} \&$ E. G. Thuranira ${ }^{1}$ \\ ${ }^{1}$ Kenya Agricultural and Livestock Research Organisation, Nairobi, Kenya \\ ${ }^{2}$ University of Nairobi, Nairobi, Kenya \\ ${ }^{3}$ International Center of Insect Physiology and Ecology, Nairobi, Kenya \\ Correspondence: C. N. Ngugi, Kenya Agricultural and Livestock Research Organisation, Nairobi, Kenya. E-mail: \\ ceciliahngugi20@gmail.com; ceciliah.ngugi@kalro.org
}

Received: July 25, 2021

doi:10.5539/jas.v13n10p107
Accepted: August 27, $2021 \quad$ Online Published: September 15, 2021

URL: https://doi.org/10.5539/jas.v13n10p107

\begin{abstract}
Globally, vegetable production including tomato is constrained by pests and diseases. The tomato leafminer, Tuta absoluta (Meyrick.), is a major pest of tomato, mainly managed using chemical pesticides. There is a need for integrated pest management (IPM), approaches that are human and environmentally friendly. The study aimed at molecular identification and virulence evaluation of four entomopathogenic nematodes (EPNs) against T. absoluta larvae. The DNA was extracted, sequenced, and phylogeny analyzed. The EPNs virulence was evaluated using the insect baiting technique at different nematode concentrations (0-Control, 100, 150, 200, and 250 infective juveniles/ml of distilled water). Larval mortality data were collected for five days. Molecular identification resulted in nucleotide sequence lengths of $877-895$ base pairs (bp). All the isolates were found to be Steinernema species of EPNs. The \% similarity of the isolates and their close relatives ranged between $82-100 \%$. The isolates closely matched Steinernema spp. AY230184 (Sri Lanka); AY230186 (Kenya), JN651414 (Ethiopia), and MW151701 (Kenya). The sequences were deposited to Genbank as Steinernema sp. Isolate Kalro 75 (MW150871), Steinernema sp. Isolate Kalro S86 (MW150872), Steinernema sp. isolate Kalro97 (MW150873) and Steinernema sp. Isolate KalroR52 (MW150874). All the EPN isolates were virulent against T. absoluta. Isolate Kalro R52 and Kalro S86 recorded the highest mortality of $76 \pm 7.5 \% ; 72 \pm 15.0 \%$ respectively in the $48 \mathrm{~h}$. There was a significant difference $(\mathrm{P}<0.001)$, between all the isolates and the Control. The four EPNs were virulent and have bio-control potential against, $T$. absoluta. Research on their virulence against $T$. absoluta in the field is recommended.
\end{abstract}

Keywords: pesticides, IPM, entomopathogenic nematodes, Steinernema sp., virulence, bio-control

\subsection{Introduction}

The use of chemical pesticides in agriculture has increased over the past decade globally. Annually an estimated 2 million tonnes of pesticides are used worldwide (Sharma et al., 2019; Choudhury \& Saha, 2020). Globally, tomato production is constrained by pests and diseases. Among major tomato pests is the tomato leafminer Tuta absoluta Meyrick, which is mainly managed using chemical pesticides that are harmful to humans and the environment (Terzidis et al., 2014; Ochilo et al., 2019). Continuous release of new pesticides formulations, lure farmers into applying them hoping for better results (Blair et al., 2014; Singh et al., 2017; Tri et al., 2017; Sharma et al., 2019; WHO \& FAO, 2019). However, food, health, and environmental safety concerns have led to a shift to integrated pest management (IPM) strategies. Such strategies are the deployment of biological pest control agents, including entomopathogenic nematodes (EPNs) (Sanda \& Sunusi, 2016; Belien, 2018; Singh et al., 2017; Perez-Alvarez et al., 2019; Surendra, 2019).

Soil inhibiting EPNs in the family Steinernematidae and Heterorhabditidae, are known to provide effective management of insect pests. They kill insect pests in 24-72 hours aided by symbiotic bacteria associated with them. They have gained importance due to safety on animals, do not affect non-target organisms, safe to the environment, ease of mass production, application, a commercial formulation of foliar applications, and exemption from registration rigors (Gozel \& Kasap, 2015; Abate et al., 2020; Yuksel \& Canhilal, 2019; Saleh et al., 2020). The EPNs as bio-control agents have been successful in the control of mainly soil-borne pests, though their use against above-ground pests has also been reported. Insect pests like leafminers, form mines/galleries on plants as they feed. 
The mines/galleries favor nematode infective juveniles (IJs), survival, and protection from adverse environmental conditions (U.Gozel \& C.Gozel, 2016; Lacey \& Georgis, 2012; Ndereyimana et al., 2019). The search for indigenous EPN strains and species coupled with virulence evaluation on agricultural pests is crucial in the use of EPN as pest bio-control agents (Batista et al., 2014; Acharya et al., 2020; Ngugi et al., 2020). This study aimed at the molecular identification and virulence evaluation of four indigenous EPNs on Tuta absoluta (Mayrick) in Kenya.

\section{Materials and Methods}

\subsection{Entomopathogenic Nematode Isolation}

The four entomopathogenic nematodes (EPNs) isolates used in this study were Laboratory cultures maintained at Kenya Agricultural and Livestock Research Organisation-Horticulture Research Institute (HRI)-Thika. The isolates had been isolated from soils in different parts of Kenya in 1997 and 2006. The isolate Karlo S86 was from Coast, R52 from Central highlands while Karlo75 and 97 were from the Rift valley (Waturu et al., 1998; Mwaniki, 2008).

Soil samples (top-soils 0-30 cm deep) from each location were put in well-labeled sterile plastic bags and stored at 4-7 ${ }^{\circ} \mathrm{C}$ in the EPN laboratory at KALRO Mwea. The isolates were later transferred to KALRO-HRI-Thika. The nematodes were multiplied and maintained according to methods described by Bedding and Akhurst (1975); White (1927), using the Greater wax moth (Galleria mellonella) pre pupa larvae.

\subsection{Insect Cultures}

The Galleria mellonella and Tuta absoluta cultures were established from the insect life stages obtained from beekeepers and tomato farmers respectively. The G. mellonella were raised in the laboratory on an artificial diet; $45 \mathrm{~g}$ bee wax, $95 \mathrm{~g}$ brewer's yeast, $307 \mathrm{~g}$ maize flour, and $225 \mathrm{~g}$ honey (Waturu, 1998). The culture of T. absoluta was maintained on tomato crop in a screen house at KALRO-HRI-Thika.

\subsection{Entomopathogenic Nematodes DNA extraction, PCR, and Sequencing}

Fresh female EPNs of each isolate were extracted from a five-day-old infected G. mellonella cadavers. The cadavers were dissected in Ringer's solution and female nematodes were picked. The DNA of the EPN isolates was extracted according to Caoili et al. (2017) protocol. The resultant DNA was quantified and purity was assessed through spectrophotometry. The Polymerase Chain Reaction (PCR) was conducted according to Hominick et al. (1997). The TW81-F (5'-GTTTCCAGTAGGTGAACCTGC-3') and AB28-R (5'-ATATGCTTAAGTTCAGC GGGT-3') primers were used for the ITS rDNA amplification. The conditions for the PCR were 35 cycles per minute at $94{ }^{\circ} \mathrm{C}$ for $5 \mathrm{~min}, 94^{\circ} \mathrm{C}$ for $1 \mathrm{~min}, 55^{\circ} \mathrm{C}$ for $1 \mathrm{~min}, 72{ }^{\circ} \mathrm{C}$ for $2 \mathrm{~min}$, and $72{ }^{\circ} \mathrm{C}$ for $5 \mathrm{~min}$. Electrophoresis was conducted on $1.5 \%$ agarose gel at 160 volts for $1 \mathrm{hr}$. The DNA was sequenced by Macrogen Inc. in Korea.

\subsection{Sequence and Phylogenetic Analysis}

The nucleotide sequence editing was done according to Hall, (1999), using Bio Edit v 7.0.5, and aligned using the MUSCLE alignment tool (Edgar, 2004; Madeira et al., 2019). The sequences were subjected to a similarity search from the NCBI database using the Basic Local Alignment Search Tool (BLASTn) (https://blast.ncbi.nlm.nih.gov) Phylogenetic (Neighbour-Joining, Distance method) tree was reconstructed from 12 best BLASTn results using SeaView version 4 bioinformatic program (Edgar, 2004; Gouy et al., 2010). The Coronavirus-2 (MW732681), was used as the out-group taxa. The bootstrap test was set at 1000 replications to determine branch support (Nguyen \& Hunt, 2007).

\subsection{Virulence of the Entomopathogenic Nematode Isolates}

The Galleria mellonella pre-pupa larvae were infected with the four EPN isolates. The odorless and spongy $G$. mellonella cadavers were randomly selected, and infective juveniles (IJs), obtained according to White, (1927), procedure. The IJs were used in the evaluation of virulence of the four indigenous EPN isolates against Tuta absoluta. Nematode doses $(0,100,150,200$, and $250 \mathrm{IJs} /)$ in $\mathrm{ml}$ of distilled water were used in the experiment. The experiment comprised five treatments in five replicates for each EPN isolate all in a completely randomized design (CRD). In the Control (0), nematodes IJs excluded in the one (1) $\mathrm{ml}$ of distilled water used. Data on insect mortality was collected daily for 5 days.

\subsection{Data Analysis}

The larval mortality data were subjected to analysis of variance (ANOVA) using Statistical software, Genstat $15^{\text {th }}$ edition. Means were separated using Fisher's protected least significant difference test at a 5\% significance level. Results were presented graphically and in tables. 


\section{Results}

\subsection{Sequence and Phylogenetic Analysis}

The lengths of the rDNA nucleotide sequences obtained were between $877-895 \mathrm{bp}$ as shown in Table 1 . The base composition on average among the isolates was Adenine (A) $29 \%$; Cytosine (C) $23 \%$; Guanine (G) $21.7 \%$ and Thymine (T) $26.1 \%$. Individual EPN isolate base composition is summarised in Table 1 .

Table 1. Entomopathogenic nematode sequence length

\begin{tabular}{llllll}
\hline \multirow{2}{*}{ Nematode isolates } & \multirow{2}{*}{ Sequence length } & \multicolumn{4}{c}{ \% Nucleotide bases } \\
\cline { 3 - 5 } & & $\mathrm{A}$ & $\mathrm{C}$ & $\mathrm{G}$ & $\mathrm{T}$ \\
\hline Isolate Karlo75 & $877 \mathrm{bp}$ & 25 & 20.8 & 26.5 & 27.8 \\
Isolate KarloS86 & $881 \mathrm{bp}$ & 30.8 & 25.2 & 17.8 & 26.2 \\
Isolate KarloR52 & $815 \mathrm{bp}$ & 32.4 & 25.3 & 17.8 & 24.5 \\
Isolate Karlo97 & $895 \mathrm{bp}$ & 28.3 & 21.5 & 24.6 & 25.7 \\
\hline
\end{tabular}

Note. $\mathrm{A}=$ Adenine, $\mathrm{C}=$ Cytosine, $\mathrm{G}=$ Guanine, $\mathrm{T}=$ Thymine.

Phylogeny study of the four isolates alone resulted in a tree with two major clades each comprising of two closely related EPN isolates. The isolate Kalro75 clustered with Kalro97 while Kalro52 and S86 grouped (Figure 1).

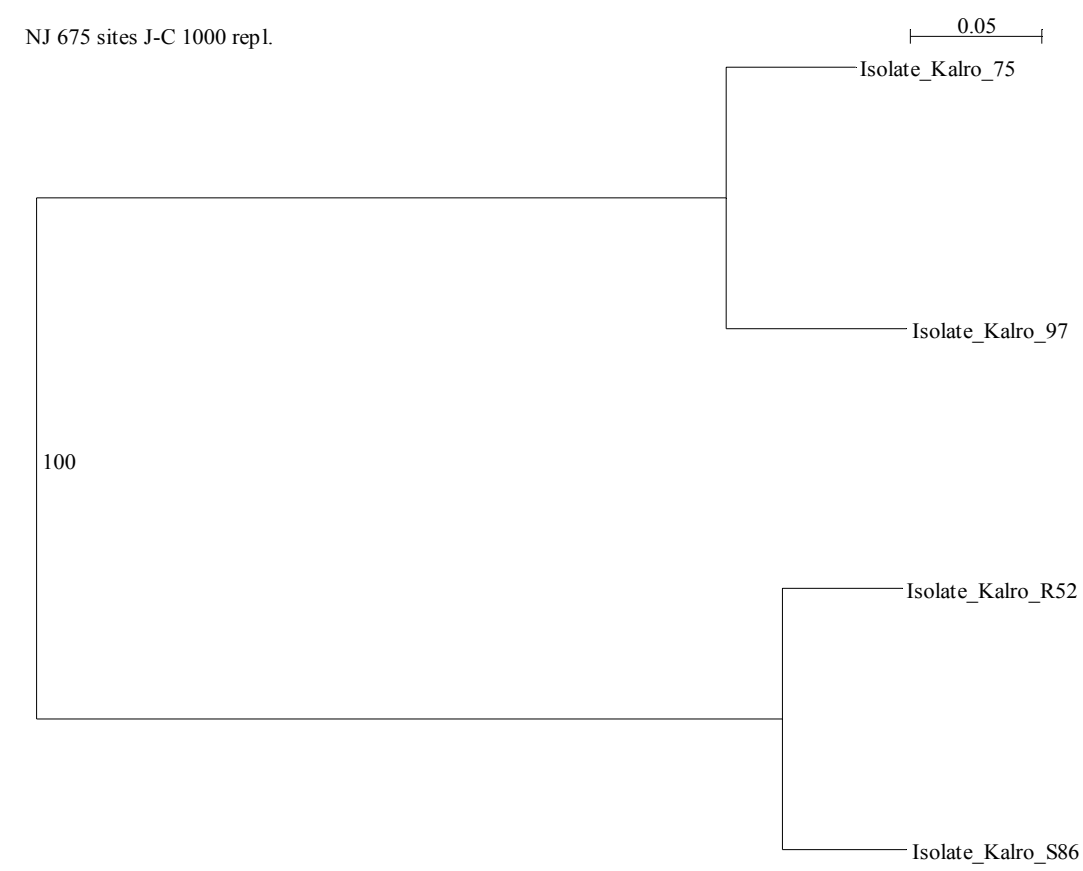

Figure 1. Phylogeny analysis based on ITS of rDNA of the four nematode isolates by Distance Neighbour-Joining Method

The multiple sequence alignment of ITS rDNA of the EPN isolates compared with GenBank accessions revealed that the isolates belonged to the EPN genus Steinernema species. The phylogenetic tree reconstructed resulted in two major clades of Steinernema spp. All the four EPN isolates were in the same clade where they clustered with Genbank accessions, Steinernema spp. AY230184 (Sri Lanka); AY230186 (Kenya); JN651414 (Ethiopia) and MW151701 (Kenya) (Spiridonov et al., 2004; Tamiru et al., 2013; Ngugi et al., 2021). The \% similarity of the isolates and their close relatives ranged between $82-100 \%$. Isolate Kalro 75 was closely related to a Kenyan Steinernema sp. isolate Kalro (MW151701) with a similarity of $100 \%$. The isolate KalroS86 was closely related to accession Steinernema sp. AY230186 from Kenya. The Genbank accession MW732681 (Corona virus-2) was the most divergent species (Figure 2). 


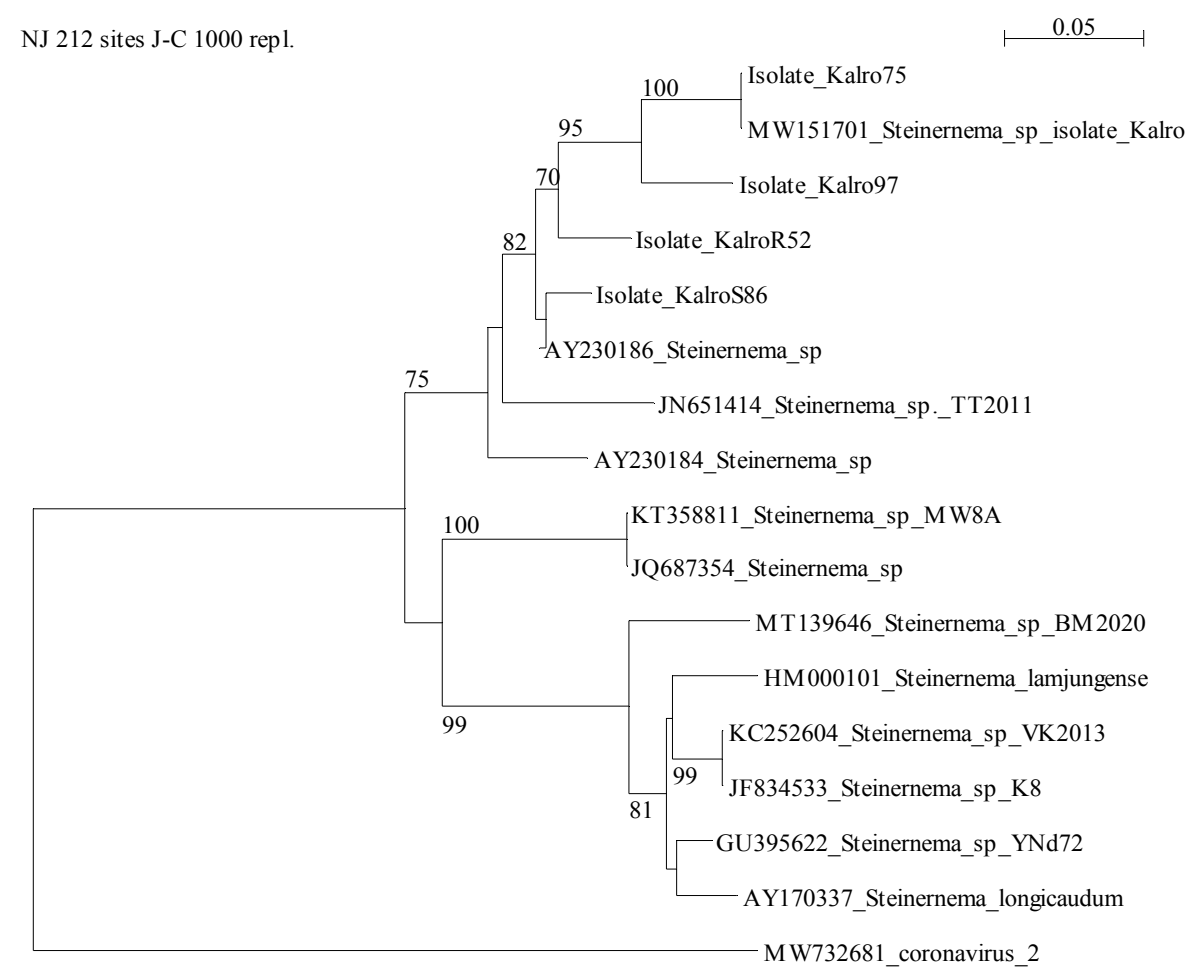

Figure 2. Phylogenetic relationships (Neighbour-Joining-method) based on ITS of rDNA sequences of the four nematode isolates (Kalro75, Kalro97, KalroR52, and KalroS86) with 12 Steinernema spp. from Genbank.

Numbers on branches are bootstrap values for clades supported above the $70 \%$ level

\subsection{Virulence of Entomopathogenic Nematode Isolates}

All the nematode isolates were virulent on larvae of Tuta absoluta causing death two days ( $48 \mathrm{~h}$ ) after infection. No larval mortality was observed in the Control experiment. Isolate KalroR52 was the most virulent at nematode suspension of $150 \mathrm{IJs} / \mathrm{ml}$ of distilled water, with \% mean larval mortality of $76 \pm 7.5$. The least virulent isolate was Kalro97 with a mean mortality \% of $36 \pm 4.0$ (Figure 3). In descending order of virulence, the isolates were

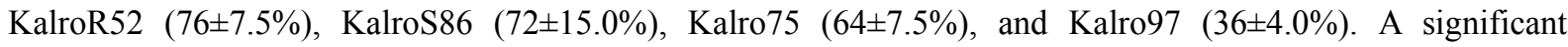
difference $(\mathrm{P}<0.001)$ between all the four EPN isolates and the Control (Zero nematodes) was observed. In addition, there was a significant difference $(\mathrm{P}<0.001)$ between isolates KalroR52, Kalro75, KalroS86, and Kalro97 (Figure 3).

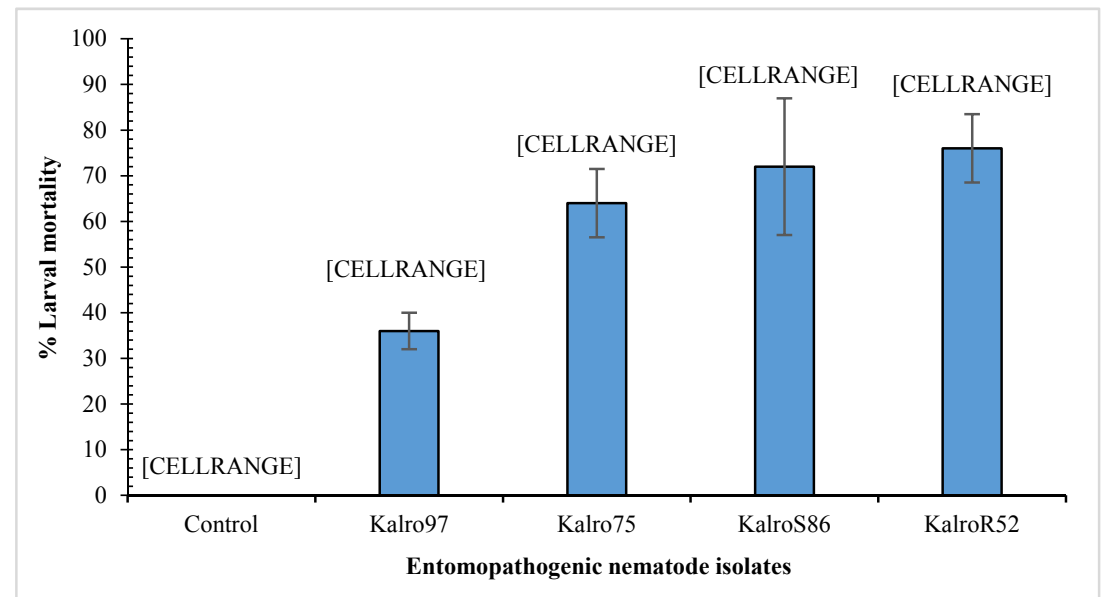

Figure 3. Virulence of the entomopathogenic nematode isolates on Tuta absoluta 


\section{Discussion}

Results from molecular identification of the isolates confirmed the four EPNs were Steinernema species clustered into two categories of two isolates each (isolate Kalro75 and Kalro97; KalroR52 and S86). This could have resulted from differences in the genetic makeup of each isolate. This was supported by sequence analysis where the nucleotide base pair percentages were very close among the pair of isolates in each cluster. According to Stock (2002) and Noujeim et al. (2016), EPNs exhibit differences within and among species. The variations in species and strains are an important consideration in the use of EPN as a biological pest control agent (Shapiro-Ilan, 2012; Gozel, 2016). The generated phylogenetic tree with isolates sequences and those retrieved from Genbank confirmed relatedness with already described EPN species. There were two major clades within the study EPN isolate clustering with Accessions, Steinernema spp. AY230184 (Sri Lanka); AY230186 (Kenya); JN651414 (Ethiopia), and MW151701 (Kenya). This suggested close evolutionary and geographical relatedness among the four isolates with the already identified Steinernema spp. It has been reported that climate influences the distribution of EPNs globally. The geographical distribution of EPNs is a biological resource necessary in the utilization of native species for biological pest and disease control (Hominick, 2002; Tarasco, 2014).

All the Four EPN isolates were virulent against Tuta absoluta larvae while no death was observed in the Control experiment. Virulence of 95 and $100 \%$, at $150 \mathrm{IJs} / \mathrm{ml}$ was reported by Khanum and Javed (2020), from EPNs. Steinernema pakistanense NNRC-AS.04 and S. bifurcatum NNRC-As.65 respectively against termites (Coptotermes heimi. Wasmann). The nematode concentration of $150 \mathrm{IJ} / \mathrm{ml}$ resulted in insect mortality of $>60 \%$ among KalroR52, S86, and 75. This pest mortality was higher than mortality caused by some synthetic pesticides like Malathion with 51.7\% mortality $72 \mathrm{~h}$ after application against Fall Armyworm (FAW) was reported by Sisay et al. (2019). According to Batalla-Carrera et al. (2010), Jacobson and Martin (2011), and Ngugi et al. (2021), the EPNs Steinernema carpocapsae, S. feltiae, Steinernema spp.-Kalro, and Heteroherbditis bacteriophora are lethal to T. absoluta larvae. For EPNs to qualify for bio-control, they should be virulent against the target pest (Shapiro-Ilan, 2015; Shehata et al., 2019).

The level of virulence, by insect mortality, differed among the isolates at the same nematode concentration. The isolates were from different parts of Kenya, with Kalro52 that was from Central highlands that are known for tomato production being the most virulent to $T$. absoluta. It's suggested that probably climatic conditions of these areas influenced the virulence of the EPN isolates against $T$. absoluta. In addition, EPN species host-finding characteristic varies among the Steinernema species or strains (Poinar \& Grewal, 2012; Nguyen et al., 2018).

\section{Conclusions and Recommendations}

The molecular analysis of ITS rDNA indicated that the four study isolates were Steinernema species of EPNs. The sequences are deposited as Genbank Accessions Steinernema sp. isolate Kalro75 (MW150871), Steinernema sp. isolate Kalro S86 (MW150872), Steinernema sp. isolate Kalro97 (MW150873) and Steinernema sp. isolate KalroR52 (MW150874). The four EPN isolates were virulent against T. absoluta larvae. Screen-house and field trials to evaluate the virulence of the isolates are recommended towards the development of EPN based bio-control against tomato leafminer, Tuta absoluta (Meyrick.).

\section{Reference}

Acharya, R., Yeon-Su, Y., Jae-Kyoung, S., \& Kyeong-Yeoll, L. (2020). Virulence of four entomopathogenic nematodes against the Tobacco Cutworm Spodoptera litura Fabricius. Biological Control, 150, 104348. https://doi.org/10.1016/j.biocontrol.2020.104348

Batalla-Carrera, L., Morton, A., \& García-del-Pino, F. (2010). Efficacy of entomopathogenic nematodes against the tomato leaf miner Tuta absoluta in laboratory and greenhouse conditions. BioControl, 55, 523-530. https://doi.org/10.1007/s10526-010-9284-z

Batista, E. S. P., Auad, A. M., Andalo, V., \& Monteiro, C. M. (2014). Virulence of entomopathogenic nematodes (Rhabditida: Steinernematidae, Heterorhabditidae) to Spittlebug Mahanarva spectabilis (Hemiptera: Cercopidae). Arq. Institute of Biology, 81(2), 145-149. https://doi.org/10.1590/1808-1657001152012

Belien, T. (2018). Entomopathogenic nematodes as biocontrol agents of insect pests in orchards. CAB Reviews, 13(058), 1-11. https://doi.org/10.1079/PAVSNNR201813058

Blair, A., Ritz, B., Wesseling, C., \& Freeman, L. B. (2014). Pesticides on human health. Occupational and Environmental Medicine, 0, 1-2. https://doi.org/10.1136/oemed-2014-102454

Choudhury, P. P., \& Saha, S. (2020). Dynamics of pesticides under changing climatic scenario. Environmental Monitoring and Assessment, 192, 814. https://doi.org/10.1007/s10661-020-08719-y 
Edgar, R. C. (2004). MUSCLE: Multiple sequence alignment with high accuracy and high throughput. Nucleic Acids Research, 32(5), 1792-1797. https://doi.org/10.1093/nar/gkh340

Gozel, C., \& Kasap, I. (2015). Efficacy of entomopathogenic nematodes against Tomato leafminer, Tuta absoluta (Meyrick) (Lepidoptera: Gelechiidae) in the tomato field. Turke. Entomolo. Derge, 39(3), 229-237. https://doi.org/10.16970/ted.84972

Gozel, U., \& Gozel, C. (2016). Entomopathogenic nematodes in pest management. In G. Harsimran \& G. Gaurav (Eds.), Integrated Pest Management (IPM): Environmentally Sound Pest Management. https://doi.org/ $10.5772 / 63894$

Grant, C., Jacobson, R., Ilias, A., Berger, M., Vasakis, E., Bielza, P., ... Bass, C. (2019). The evolution of multiple-insecticide resistance in UK populations of Tomato Leafminer, Tuta absoluta. Pest Management Science, 75(8), 2079-2085. https://doi.org/10.1002/ps.5381

Hall, T. A. (1999). Bio Edit: A user-friendly biological sequence alignment editor and analysis program for Windows 95/98/NT. Nucleic Acids Symposium Series, 41, 95-98. https://doi.org/10.14601/Phytopathol_ Mediterr-14998u1.29

Hominick, W. M. (2002). Biogeography. In R. Gaugler (Ed.), Entomopathogenic nematology (pp. 115-143). CABI Publishing, Wallingford, UK. https://doi.org/10.1079/9780851995670.0115

Hominick, W. M., Briscoe, B. R., del Pino, F. G., Heng, J., Hunt, D. J., Kozodoy, E., ... Yoshida, M. (1997). Biosystematics of entomopathogenic nematodes: Current status, protocols, and definitions. Journal of Helminthology, 71(4), 271-298. https://doi.org/10.1017/s0022149x00016096

Jacobson, R., \& Martin, G. (2011). A potential role for entomopathogenic nematodes within IPM of Tuta absoluta (Meyrick) on organic tomato crops. IOBC/WPRS Bulletin, 68, 79-83.

Khanum, T. A., \& Javed, S. (2020). Virulence of four Steinernema species as a biological control agent in controlling the termite, Coptotermes heimi (Wasmann) (Isoptera: Rhinotermitidae). Egypt Journal of Biological Pest Control, 30(26), 1-4. https://doi.org/10.1186/s41938-020-00229-w

Lacey, L. A., \& Georgis, R. (2012). Entomopathogenic nematodes for control of insect pests above and below ground with comments on commercial production. Journal of Nematology, 44(2), 218-225.

Madeira, F., Park, Y. M., Lee, J., Buso, N., Gur, T., Madhusoodanan, N., ... Lopez, R. (2019). The EMBL-EBI search and sequence analysis tools APIs in 2019. Nucleic Acids Research, 47(1), 636-641. https://doi.org/ 10.1093/nar/gkz268

Mwaniki, S., John, H., Olubayo, F., Kimenju, J., \& Nguyen, K. (2008). Factors influencing the occurrence of entomopathogenic nematodes in the Central Rift Valley Region of Kenya. African Journal of Ecology, 46, 79-84. https://doi.org/10.1111/j.1365-2028.2008.00933.x

Ndereyimana, A., Nyalala, S., Murerwa, P., \& Gaidashova, S. (2019). Potential of entomopathogenic nematode isolates from Rwanda to control the tomato leaf miner, Tuta absoluta (Meyrick) (Lepidoptera: Gelechiidae). Egypt Journal of Biological Pest Control, 29(57), 1-7. https://doi.org/10.1186/s41938-019-0163-3

Ngugi, C. N., Wachira, P. M., Mbaka, J. N., Okoth, S., Haukeland, S., Mburu, H. M., ... Sirengo, D. K. (2021). Characterisation and pathogenicity test of entomopathogenic nematode Steinernema species-Kalro. Journal of Agricultural Science, 13(3), 93-101. https://doi.org/10.5539/jas.v13n3p93

Nguyen, C. N., Do, A. T., Trinh, P. Q., \& Hoang, P. K. (2018). Virulence of two entomopathogenic nematode species, Steinernema sp. (strain PQ16) and Heterorhabditis indica (strain KT3987), to nymphs of the coffee Cicada Dundubia nagarasingna. Nematology, 0, 1-10. https://doi.org/10.1163/15685411-00003193

Nguyen, K. B., \& Hunt, D. (2007). Entomopathogenic nematodes: Systematics, phylogeny, and bacterial symbionts. Nematology monographs and perspectives (Vol. 5, p. 816). Brill, Leiden-Boston, The Netherland. https://doi.org/10.1163/ej.9789004152939.i-816

Noujeim, E., Sakr, J., Fanelli, E., Troccoli, A., Pages, S., Tarasco, E., \& Luca, F. (2016). Phylogenetic relationships of entomopathogenic nematodes and their bacterial symbionts from Coastal areas in Lebanon. Redia, XCIX, 127-137. http://doi.org/10.19263/Redia-99.16.16

Ochilo, W. N., Nyamasyo, G. N., Kilaloc, D., Otieno, W., Otipa, M., Chege, F., ... Lingeera, E. K. (2019). Characteristics and production constraints of smallholder tomato production in Kenya. Scientific African, 2, e00014. https://doi.org/10.1016/j.sciaf.2018.e00014 
Perez-Alvarez, R., Nault, B. A., \& Poveda, K. (2019). Effectiveness of augmentative biological control depends on landscape context. Scientific Reports, 9(8664), 1-15. https://doi.org/10.1038/s41598-019-45041-1

Poinar, Jr. G. O., \& Grewal, P. S. (2012). History of entomopathogenic nematology. Journal of Nematology, 44(2), 153-161.

Saleh, M. M. E., Metwally, H. M. S., \& Abonaem, M. (2020). Commercialization of biopesticides based on entomopathogenic nematodes. In N. El-Wakeil, M. Saleh, \& M. Abu-Hashim (Eds.), Cottage Industry of Biocontrol agents and their applications. Springer, Cham. https://doi.org/10.1007/978-3-030-33161-0_8

Sanda, N. B., \& Sunusi, M. (2016). Fundamentals of biological control of pests. International Journal of Chemical and Biological Science Review Paper, 1(6), 1-12. https://doi.org/10.13140/RG.2.2.19011.20002

Shapiro-Ilan, D. I., Han, R., \& Dolinksi, C. (2012). Entomopathogenic nematode production and application technology. Journal of Nematology, 44(2), 206-217.

Shapiro-Ilan, D. I., Hazir, S., \& Lete, L. (2015). Viability and virulence of entomopathogenic nematodes exposed to ultraviolet radiation. Journal of Nematology, 47(3), 184-189.

Sharma, A., Kumar, V., Shahzad, B., Tanveer, M., Sidhu, G. P. S., Handa, N., ... Thukra, A. K. (2019). Worldwide pesticide usage and its impacts on ecosystem. Spring Nature Applied Science, 1, 1446. https://doi.org/ $10.1007 / \mathrm{s} 42452-019-1485-1$

Shehata, I. E., Hammam, M. M. A., El-Borai, F. E., Duncan, L. W., \& Abd-Elgawad, M. M. M. (2019). Comparison of virulence, reproductive potential, and persistence among local Heterorhabditis indica populations for the control of Temnorhynchus baal (Reiche and Saulcy) (Coleoptera: Scarabaeidae) in Egypt. Egypt Journal Biological Pest Control, 29(32), 1-9. https://doi.org/10.1186/s41938-019-0137-5

Shiberu, T., \& Getu, E. (2017). Estimate of yield losses due to Tuta absoluta Meyrick (Lepidoptera: Gelechiidae) on tomato crops under glasshouse and field conditions in Western Shewa of Central Ethiopia. International Journal of Fauna and Biological Studies, 4(5), 104-108. https://www.researchgate.net/publication/ 321796467

Singh, J. K., Yadav, K. K., \& Kumar, V. (2017). Integrated pest management: Conservation practices for agriculture and environment. International Journal for Environmental Rehabilitation and Conservation, $\operatorname{VIII}(2), 17-28$.

Sisay, B., Tefera, T., Wakgari, M., Ayalew, G., \& Mendesil, E. (2019). The efficacy of selected synthetic insecticides and botanicals against Fall Armyworm, Spodoptera frugiperda, in Maize. Insects, 10(45), 1-14. https://doi.org/10.3390/insects10020045

Spiridonov, S. E., Reid, A. P., Podrucka, K., Subbotin, S. A., \& Moens, M. (2004). Phylogenetic relationships within the genus Steinernema (Nematoda: Rhabditida) as inferred from analyses of sequences of the ITS1-5.8S-ITS2 region of rDNA and morphological features. Nematology, 6(4), 547-566. https://doi.org/ $10.1163 / 1568541042665304$

Stock, A. P. (2002). New trends of entomopathogenic nematodes systematics: Impact of molecular biology and phylogenetic reconstruction (pp. 1-9). The Tenth International Congress of Parasitology. Retrieved from https://www.researchgate.net/publication/267703966

Surendra, K. D. (2019). The new integrated pest management paradigm for the modern age. Journal of Integrated Pest Management, 10(1), 12. https://doi.org/10.1093/jipm/pmz010

Tamiru, T., Waeyenberge, L., Hailu, T., Ehlers, R. U., Puza, V., \& Mracek, Z. (2013). Steinernema ethiopiense sp. n. (Rhabditida: Steinernematidae), a new entomopathogenic nematode from Ethiopia. Nematology, 14(6), 741-757. https://doi.org/10.1163/156854112X627282

Tarasco, E., Clausi, M., Rappazzo, G., Panzavolta, T., Curto, G., Sorino, R., ... Triggiani, O. (2015). Biodiversity of entomopathogenic nematodes in Italy. Journal of Helminthology, 89(3), 359-366. https://doi.org/ $10.1017 / \mathrm{S} 0022149 \mathrm{X} 14000194$

Terzidis, A. N., Wilcockson, S., \& Leifert, C. (2014). The tomato leaf miner (Tuta absoluta): Conventional pest problem, organic management solutions? Organic Agriculture, 4, 43-61. https://doi.org/10.1007/s13165014-0064-4

Waturu, C. N. (1998). Entomopathogenic nematodes (Steinernematidae and Heterorhabdtidae) from Kenya (p. 191, PhD Thesis, University of Reading, UK). 
White, G. F. (1927). A method of obtaining infective nematode larvae from cultures. Science, 66(1709), 302-303. https://doi.org/10.1126/science.66.1709.302-a

World Health Organization \& Food and Agriculture Organization of the United Nations. (2019). Global situation of pesticide management in agriculture and public health. Report of a 2018 WHO-FAO survey. World Health Organization. Retrieved from https://apps.who.int/iris/handle/10665/329971

Yuksel, E., \& Canhilal, R. (2019). Isolation, identification, and pathogenicity of entomopathogenic nematodes occurring in Cappadocia Region, Central Turkey. Egypt Journal of Biological Pest Control, 29(40), 1-7. https://doi.org/10.1186/s41938-019-0141-9

\section{Copyrights}

Copyright for this article is retained by the author(s), with first publication rights granted to the journal.

This is an open-access article distributed under the terms and conditions of the Creative Commons Attribution license (http://creativecommons.org/licenses/by/4.0/). 